DOI: http://dx.doi.org/10.26858/est.v1i1.7038

\title{
Entrepreneurship Interests Students Viewed From Internship Experience and Role Of Teachers
}

\author{
Nurhuda $^{1}$, Soenarto ${ }^{2}$ \\ ${ }^{1}$ Technology and Vocational Education, Yogyakarta State University, Indonesia \\ Email: jurnalnurhuda@gmail.com \\ ${ }^{2}$ Faculty of Engineering, Yogyakarta State University, Indonesia \\ Email: soenarto@uny.ac.id
}

(Received: October-2018; Reviewed: November-2018; Accepted: November-2018; Published: December-2018)

(C)2018 -EST Postgraduate Program Makassar State University. This is an article with open access under license CC BY-NC-4.0 (https://creativecommons.org/licenses/by-nc/4.0/).

\begin{abstract}
This study aims to reveal the experience of internship and the role of teachers in the interests of student entrepreneurship. This study uses the ex-post facto method with a quantitative approach. The study population was vocational students in the Technical and Informatics Expe rtise Program in Buol District, which was precisely 160 students. The number of research samples is 113 students using proportional random sampling techniques. Data collection uses questionnaires. Data analysis used multiple regression analysis. The results showed that partially the internship experience (24.19\%) and the role of the teacher $(13.61 \%)$ had a positive and significant influence on the interest in entrepreneurship. While simultaneously the two variables are insightful for entrepreneurship interests of $37.8 \%$. These results indicate that the experience of internship and the role of teachers are more so that it can produce vocational graduates not only ready to work but also able to entrepreneurship.
\end{abstract}

Keywords: internship experience, teacher's role, interest in entrepreneurship

\section{INTRODUCTION}

Indonesia has abundant natural resources, to become a developed country requires quality human resources. One of the Indonesian government's efforts to fulfill human resources is through vocational secondary education. Vocational secondary education has a role in preparing students to be ready for work and can open their own business. This is in accordance with Law No. 20 of 2003 article 15 which states that vocational secondary education aims to prepare students to work in certain fields.

Data obtained from the Central Statistics Agency (BPS 2017) of Central Sulawesi
Province shows that vocational school graduates are in second place contributing to unemployment after high school which is equal to $5.12 \%$. To overcome the lack of employment, the government included entrepreneurship subjects in the school curriculum. The goal is that after graduation students will be able to open their own business. Therefore the role of the teacher is needed in fostering interest in student entrepreneurship. This interest in entrepreneurship is characterized by the desire, interest and willingness of someone to work independently in fulfilling their life needs with confidence and without being afraid of the risks 
they will face and always learning from experience.

Entrepreneurship teachers in vocational high schools are expected to develop their potential to produce graduates who are not only ready to work but also can create a field for employment. Leino JS et al. (2010) explained that teachers are key in promoting entrepreneurship education. Teachers must be creative and innovative in the learning process in instilling the entrepreneurial spirit of students in the School. Prosser explains that Vocational education will be effective in proportion as the instructor has had successful experience's in the application of skill and knowledge to the operations and processes he undertakes to teach (crafts person teacher) (Sudira, 2016: 31)

Heck and Williams (1984, 1-188) describe 10 roles of teachers in education The Teacher as Person: A Caring Role; The Teacher as Colleague: A Supporting Role; Teacher and Parents as Partners: A Complementary Role; The Teacher as Understands of the Learner: A Nurturing Role; The Teacher as Facilitator of Learning: An Interacting Role; The Teacher as Researcher: An Experimenting Role; The Teacher as Developer Program: A Creating Role; The Teacher as Administrator: A Planning Role; The Teacher as Decision Maker: A Problem-Solving Role and The Teacher as Professional Leader: A Challenging Role. Simpson, D. J, Jackson MP, Aycock JC \& Oaks T. (2007) also explained the role of teachers according to John Dewey, namely the teacher as artist, lover, wise mother, navigator, gardener, educational pioneer, servant, social engineer, composer, wise physician, builder, leader.

The role of the teacher above is very diverse, but the role of the teacher can be implemented in the form of service. The role of the teacher as a professional educator has the main task of educating, teaching, guiding and training. Educating means continuing and developing the values of life and life. Teaching means continuing, bequeathing, instilling and developing science and technology. Training means developing skills in students. Guiding means understanding students' differences in terms of background, students' intellectual abilities, students' physical, and health (Husain, 2017: 67). Teachers must provide provisions for students to be more adaptive, creative and innovative through learning experiences so that students are ready to plunge into entrepreneurship. Stock can be in the form of knowledge in business, understanding of the profile of a company, knowledge analyzing growth, knowledge of ethics, capacity to see and seize business opportunities. The teacher provides this knowledge by using a number of pedagogical models and methods in entrepreneurship education, such as problembased learning, experience and description of practical situations, and they also encourage their students to be responsible and become independent (Roskovaara E. et. al, 2014, Oplatka , I., 2014; Leino JS et. al, 2015;). The role of the teacher has a contribution in shaping the interest in student entrepreneurship because the implementation of the learning process in the classroom can shape the attitudes and interests of students for entrepreneurship (Hasbi, 2017).

In addition to the teacher's role, to the develop interest in entrepreneurship students also need experience in work. Work experience can be obtained by students through internship experience activities held by Vocational High Schools. In internship activities, students can know and experience firsthand the real work situation. Hadam and Ariyadi (2017: 83) say that Industrial Work Practices is one of the learning programs taken by students in the world of work. Gunawan et al (2014) explained that internship is one form of providing vocational expertise education for students carried out outside the school (industry) that has been adapted to the needs of the world of work and industry. Industrial work practice is a field of student professional training, namely by the process of mastering skills by working directly in employment. Creativity and initiative in working in the industry will train students to develop their ideas, be more creative and take the initiative of students in developing their ideas, so students will increasingly have the desire to entrepreneurship, because entrepreneurship requires high creativity and initiative in facing competition in the industrial world. Work experience obtained by students at work can be a capital in working, especially in entrepreneurship. The purpose of internship activities is so that students have work knowledge, work attitudes, work skills and work creativity. In practical activities students are trained to work real before they graduate. Work experience gained during the internship can affect students' interest in entrepreneurship (Farouk A., et al, 2014; Hasbi, 2017; Botha, M. et al, 2016). Hurst, Jessica L., et al (2014) also said that internship activities are key in career 
preparation, professional development and career improvement for students.

The results of observations conducted in Buol Regency provided information that vocational graduates who worked were $29.41 \%$ and entrepreneurship $2.215 \%$. The data shows that vocational school graduates with entrepreneurship are very low. The lack of vocational graduates who are self-employed is due to the lack of knowledge about business, not having the capital to start a business, lack of confidence and fear of failing in business. From the results of these observations also obtained information that entrepreneurship teachers still use conventional learning patterns. Entrepreneurship teachers also have not designed and developed learning by using certain methods in order to foster creativity and a good mental attitude in students in the learning process. The average teacher who teaches entrepreneurship subjects is teachers who have an educational background that is not in accordance with effective subjects. Entrepreneurship material focuses on the practice of making products and sales practices without deepening the meaning of entrepreneurship itself so that students have not developed their potential for entrepreneurship.

On the other hand, the implementation of internship held by schools is also not optimal. The results of observations carried out by researchers in several Vocational Schools in Buol Regency were obtained by information that the Business and Industry Party (DUDI) had not fully given trust to student internship on the grounds that DUDI did not want to disappoint their clients while maintaining the quality of the company's work. In addition, there are several partner institutions that do not understand the purpose of the internship experience implementation held by Vocational High Schools (SMK) by assigning assignments to students who are not in accordance with their competencies. This is what causes the work experience of student internship very little.

Based on the above problems, the purpose of this study is to reveal the level of significance and contribution of the internship experience and the role of the teacher to students' interest in entrepreneurship. Computer and informatics engineering expertise program at Buol District Vocational School

\section{METHOD}

Research conducted using quantitative research ex-post facto. This research was carried out in 4 (four) Vocational Schools in Buol Regency. The population in this study were students of class XII Vocational High School 2017/2018 academic year who held the Computer and Informatics Engineering Expertise Program and had participated in the internship program in Buol District with 160 students. The sample of this study amounted to 113 using the proportionate random sampling technique.

The independent variable in this study is the internship experience $\left(\mathrm{X}_{1}\right)$ and teacher roles $\left(\mathrm{X}_{2}\right)$, while the dependent variable in this study is interest in sanitation (Y). Data collection techniques using questionnaires using the Likert Scale with four alternative answers namely Strongly Agree (SA) / Always (AL), Agree (A) / Often (O), Disagree (D) / Sometimes (S); and Strongly Disagree (SD) / Never (N).

Data analysis used is variable descriptive analysis, test requirements analysis and research hypothesis testing. Test requirements analysis using normality test, linearity test and multicolinearity test. Research hypothesis testing is done using multiple linear regression, $\mathrm{T}$ test, $\mathrm{F}$ test and determination (R2). Data analysis was processed using version 22 SPPS software

\section{RESULTS AND DISCUSSION}

\section{Result}

Data description in this study aims to determine the data distribution of each variable. The calculation results using the SPSS Program can be seen in table 3.1.

Tabel 3.1. Result of Describe the data for each variable

\begin{tabular}{llllllll}
\hline \multicolumn{1}{c}{ Variabel } & Item & Max & Min & Mean & $\begin{array}{c}\text { Media } \\
\text { n }\end{array}$ & $\begin{array}{c}\text { Mod } \\
\text { e }\end{array}$ & $\begin{array}{c}\text { Standard } \\
\text { deviation }\end{array}$ \\
\hline Internship experience & 24 & 96 & 62 & 83,55 & 84 & 83 & 8,124 \\
Teacher's role & 24 & 90 & 34 & 66,39 & 68 & 71 & 12,853 \\
Interest in & 24 & 91 & 59 & 77,81 & 77 & 74 & 6,782 \\
entrepreneurship & & & & & & & \\
\hline
\end{tabular}


The normality test uses the KolmogorovSmirnov test to determine whether the residual values generated from the regression are normally distributed or not. The results of the normality test obtained a significance value of 0.200 . $(0,200>0,05)$ it is concluded that the residual value is normally distributed.

Linearity test aims to determine whether each independent variable has a linear relationship with the dependent variable. The results of the linearity test in each of the practical experience variables and the teacher's role produce the Sig. Deviation From Linearity 0.770 and 0.214 . This means that the practice experience variable, and the teacher's role has a linear relationship with the entrepreneurship interest variable where the significance value is more than 0.05 .

Multicolinearity testing is done to see whether there is a correlation between the Independent variables. A good regression model should not occur multicollinearity among Independent variables. Practical experience and teacher role variables have Tolerance values and Variance Inflation Factor (VIF) values are 0.826 and 1.211. The data shows that there is no multicolinerity in the regression model.

Multiple linear regression analysis aims to see whether or not the influence of two or more independent variables on the dependent variable. The results of multiple linear regression analysis can be seen in table 3.2.

Table 3.2 Results of Multiple Linear Regression Analysis

\begin{tabular}{lcccc}
\hline \multirow{2}{*}{ Model } & \multicolumn{2}{c}{ Unstandardized Coefficients } & Standardized Coefficients \\
\cline { 2 - 6 } & B & Std. Error & Beta & \\
\hline (Constant) & 37.318 & 5.292 & & \\
Internship Experience & 0.363 & 0.069 & 0.435 & 0.289 \\
Role of Teachers & 0.153 & 0.044 & & \\
\hline
\end{tabular}

Based on Table 3.2 equation multiple regression can be written as follows:

$$
Y=37.318+0.363_{X 1}+0.153 X_{2}
$$

Equation above can be explained that the constant value of 37.318 to interpreted that if the apprenticeship experience and the teacher's role are 0 , then the interest in entrepreneurship (Y) is 37.318. The coefficient of experience in apprenticeship is 0.363 , this means that if the value of the teacher's role is 0 and the apprenticeship experience has increased one unit then the interest in student entrepreneurship will also increase by 0.363 . The role of the teacher has a coefficient of 0.153 , meaning that if the value of the experience of the apprenticeship is 0 and the coefficient of the teacher's role increases one unit, the interest in entrepreneurship will also increase. From the explanation above, it can be concluded that the higher the internship experience and the role of the teacher, the higher the interest in entrepreneurship.

The $t$ test in this study is used to determine whether or not there is a partial effect (independent) between the independent variable on the dependent variable, and whether it has a significant influence or not. The results of the $t$ test can be shown in table 3.3.

Table 3.3. Test Results $t$

\begin{tabular}{cccccc}
\hline No & Variables & $\begin{array}{c}\mathbf{t} \text { count } \\
(>\mathbf{t} \text { table })\end{array}$ & $\begin{array}{c}\mathbf{t} \\
\text { table }\end{array}$ & $\begin{array}{c}\text { Sig. } \\
(<\mathbf{0 . 0 5})\end{array}$ & Remarks \\
\hline 1 & Practical Experiences & 5,260 & 1,981 & 0,000 & Significant \\
2 & The role of the teacher & 3,497 & 1,981 & 0,001 & significant \\
\hline
\end{tabular}

Table 3.3 shows that the practice experience variables and the teacher's role have a positive and significant effect on entrepreneurial interest. This is seen from the value of $\mathrm{t}$ count more than 1.981 and the significance value is less than 0.05 so that the first hypothesis can be accepted by $\mathrm{H} 1$ and rejects $\mathrm{H} 0$ and the second hypothesis receives $\mathrm{H} 2$ and rejects $\mathrm{H} 0$.

The F test is used to find out whether or not the influence between the independent 
variables together with the dependent variable. The $\mathrm{F}$ test results are shown in table 3.4

Table. 3.4 Test F

\begin{tabular}{llrrrrr}
\hline & Model & Sum of Squares & Df & Mean Square & F & \multicolumn{1}{c}{ Sig. } \\
\hline 1 & Regression & 1947,792 & 2 & 973,896 & 33,437 & $.000^{\mathrm{b}}$ \\
& Residual & 3203,925 & 110 & 29,127 & & \\
& Total & 5151,717 & 112 & & & \\
\hline
\end{tabular}

Table 3.4 displays the $\mathrm{F}$ value of 33.437 $\left(\mathrm{F}_{\text {count }}\right)<2.45\left(\mathrm{~F}_{\text {table }}\right)$ with significance value of 0.000 . $\quad(0,000<0,05)$. From these data concluded that the third hypothesis accepting $\mathrm{H} 3$ rejects $\mathrm{H} 0$, which means that there is an influence of the practical experience and the role of the teacher simultaneously on the interest in entrepreneurship.
The coefficient of determination (R2) is used to determine the percentage of the contribution of the influence of the independent variables simultaneously on the dependent variable. The results of the analysis of the coefficient of determination are shown in table 3.5 .

Table 3.5 Results of Analysis of Determination Coefficient

\begin{tabular}{ccccc}
\hline Model & R & R Square & $\begin{array}{c}\text { Adjusted R } \\
\text { Square }\end{array}$ & $\begin{array}{c}\text { Std. Error of the } \\
\text { Estimate }\end{array}$ \\
\hline 1 & $0.615^{\mathrm{a}}$ & 0.378 & 0.367 & 5,39691 \\
\hline
\end{tabular}

Table 3.5 shows that the value of Adjusted $\mathrm{R}$ Square is 0.367 . This value shows that the percentage of influence of apprenticeship experience and teacher's role on entrepreneurship interest is $37.8 \%$ and $62.2 \%$ is influenced by other factors.
Relative donations and effective contributions are used to determine how much influence the influence of each independent variable on the dependent variable. The results of these calculations can be seen in table 3.6.

Table 3.6 Contribution of

\begin{tabular}{cccc}
\hline No & Variable & $\begin{array}{c}\text { Effective } \\
\text { Contributions (\%) }\end{array}$ & Relative Donations (\%) \\
\hline 1 & Internship Experience & 24,19 & 64 \\
2 & The Role of Teachers & 13,61 & 36 \\
\hline
\end{tabular}

Table 3.6 shows that effective contribution given by apprenticeship experience variable to student entrepreneurship interest is $24,19 \%$ with relative contribution of $64 \%$. On the other hand, the effective contribution given by the teacher's role variable on interest in entrepreneurship is $13,61 \%$ and the contribution of the relative contribution is $36 \%$.

\section{Discussion}

Effects of Internship Experience on students' interest in entrepreneurship

The results of the testing of the first hypothesis (H1) show that the variable experience of internship has a positive and significant influence on the interest in entrepreneurship in vocational students in the Computer and Informatics Engineering Expertise Program in Buol Regency. The data from the calculation of effective contributions shows that the effective contribution given by the internship experience to the interest in entrepreneurship is $24.19 \%$. This study supports the results of research conducted by Chou, Shen, Hsiao \& Chen (2014); Fatoki (2014); Chou CM \& Shen CH (2015); Gunawan IWW, Nuridja IM \& Suharsono N. (2014), who explained that the experience of internship affects the interest in entrepreneurship. Internship activities provide experience in the form of knowledge and skills in the industrial world directly and in accordance with the actual situation. Internship activities help students in applying the theories that have been obtained in school with the Practices that they do in the workplace which is actually the Industrial World. Anramus (2015) explained that in order to improve the quality of vocational school graduates, during the 
internship activities students are placed in the right, relevant and appropriate industries. Someone who has a level of mastery of knowledge and has experience in accordance with his field of expertise can be said to have skills, so that with the experience of the apprenticeship in addition to being ready to work, vocational graduates are also ready for entrepreneurship.

Explanation above can be concluded that the experience of internship is very instrumental in increasing students' interest in entrepreneurship. Therefore, the implication in this research is that the role of all industrial parties as users of vocational school graduates and schools as providers of quality graduates must implement appropriate practice models and systems so that they can produce graduates who are capable and entrepreneurial. in addition, the school cooperates with the Business/ Industry side to improve and be serious in handling apprenticeship activities, especially in selecting places of internship and assignments that are appropriate to the field of expertise of students.

The influence of the teacher's role on the interests of student entrepreneurship

The results of testing the second hypothesis (H2) show that the role of the teacher gives a positive influence on the interest in entrepreneurship in vocational students in the Computer and Informatics Engineering Expertise Program in Buol Regency. The data shows that Entrepreneurship Knowledge of Vocational Students in the Computer and Informatics Engineering Expertise Program in Buol Regency. While the research data shows that the Effective Contribution of the Teacher's Role to Student Entrepreneurship Interest is $13.61 \%$. The results of this study are supported by research conducted by Hasbi (2017) and Iswanu (2016) which explains that the role of teachers is influential and has a contribution in fostering interest in student entrepreneurship. Therefore, it is expected that the role of entrepreneurship teachers must be increased. Entrepreneurship teachers in schools are teachers who have an educational background that is in accordance with the subjects taught; teachers who have experience in entrepreneurship; and productive teachers or teachers who have taken entrepreneurship training. in addition, entrepreneurship teachers in schools must be able to educate and introduce students to the business world, so that students have an interest in entrepreneurship after graduating later. In the learning process the teacher can guide and direct students in introducing the business world whose products are needed and in demand by the surrounding community. The teacher trains entrepreneurship students since sitting in class $\mathrm{X}$ to make products, promote products, and manage finances from the sale of their products. On the other hand, teachers also provide motivation to students so that they can take advantage of their potential for entrepreneurship, be independent in carrying out their business and students can also consult on the development of their business to their entrepreneurial teachers. The teacher can also include students in the activities of the production unit held at the school. by maximizing the teacher's role in fostering interest in student entrepreneurship, SMK graduates are not only ready to work but they are also ready to open their own jobs (entrepreneurship). The implication in this study is that teachers are more creative and innovative in increasing their role as teachers, coaches, instructors and educators so as to produce graduates who have the spirit and interest in entrepreneurship.

Effect of Internship Experience and the role of teachers simultaneously on students 'interest in entrepreneurship

The results of testing the third hypothesis (H3) show that the experience of internship and the role of teachers simultaneously have a positive influence on students' interest in entrepreneurship by $36.7 \%$ and the remaining $63,3 \%$ influenced by other factors. This means that the interest in entrepreneurship is not only influenced by the role of a teacher in the school environment but also needs to be supported by the work experience they obtain when participating in internship activities. so that the higher the role of the teacher and the experience of student training, the higher the interest of students' interest in entrepreneurship

\section{CONCLUSIONS AND SUGGESTIONS}

Based on data analysis and discussion of research results, it can be summarized as follows: Practical experience and the role of teachers in Buol regency both partially and simultaneously have a positive and significant effect on entrepreneurial interest in vocational students in the Computer and Informatics Engineering Expertise Program in Buol District 
have a positive and significant effect on entrepreneurial interest, with effective contributions given $24.19 \%$ apprenticeship experience and 13 teacher roles $13,61 \%$. Simultaneous effective contribution of $37.8 \%$.

From the results of the above discussion, it is suggested that cooperation between the school and industry be further enhanced. The school can socialize the objectives of the implementation of the apprenticeship to the industry, so that the industry can understand the duties and obligations in the internship activities. The school and the industry can also work together in establishing the right model and system of practice in order to produce vocational graduates not only ready to work but also able to open their own businesses.

On the other hand, in the learning process entrepreneurship teachers must be able to develop and use innovative, creative and productive learning models such as Project Based Learning models to improve the entrepreneurial character of vocational students in Buol Regency. The School puts teachers in entrepreneurial subjects according to their competence or who have experience in entrepreneurship, or productive teachers. In addition, the school program programs entrepreneurship training to teachers, especially entrepreneurship teachers. This is a standard for determining the quality of graduates not produced by vocational schools.

\section{REFERENCES}

Anramus (2012). Kontribusi Praktik Kerja Industri dan Motivasi Belajar terhadap Sikap Wirausaha. INVOTEC, Volume VIII, No.2, Sepember 2012. Hal. 108-114

Badan Pusat Statistik Provinsi Sulawesi Tengah. (2017). Berita Resmi Statistik BPS Sulawesi Tengah No.26/05/72/Th. XX, 05 Mei 2017. https://buolkab.bps.go.id/ edit/brs_ind/ brsInd-20170621032449.pdf.

Botha, M., \& Bignotti, A. (2016). Internships enhancing entrepreneurial intent and selfefficacy: Investigating tertiary-level entrepreneurship education programmes. The Southern African Journal of Entrepreneurship and Small Business
Management, $\quad 8(1)$

doi:10.4102/sajesbm.v8i1.45

Chou, C.M. \& Shen, C.H. (2015). Tertiary Students' Entrepreneurship Learning Socialization: Factor Analysis and Structural Equation Modeling, International Journal of Psychology and Educational Studies. Vol 2. No.3. Hal. 3238.

Chou, C. M., Shen, C.H., Hsiao, H.C.,\& Chen, S.C. (2014). Factors Affecting Entrepreneurial Internship Effectiveness In It Industry: A Structural Equation Modeling. Review of Industrial Engineering Letters, 2014, 1(1): 36-43. DOI: $\quad 10.18488 /$ journal.71/ 2014.1.1/71.1.36.43.

Farouk A. \& Ikram A.,. (2014). The Influence Of Individual Factors On The Entrepreneurial Intention. International Journal of Managing Value and Supply Chains (IJMVSC) Vol. 5, No. 4, December 2014. DOI: 10.5121/ijmvsc.2014.5404 47

Fatoki, O. (2014). The Entrepreneurial Intention of Undergraduate Students in South Africa:The Influences of Entrepreneurship Education and Previous Work Experience. Mediterranean Journal of Social Sciences, MCSER Publishing, Rome-Italy, Vol. 5 No. 7. 294- 299. Doi:10.5901/mjss.2014. v5n7p294

Gunawan I.W.W, Nuridja I.M \& Suharsono N. (2014). Pengaruh Pengalaman Prakerin terhadap minat berwirausaha Siswa XI Jurusan Pemasaran SMKN 1 Klukung 2012/2013. Jurnal Pendidikan Ekonomi Undiksha. Volume 4 No. 1.

Hadam S. R. \& Ariyadi. (2017). Strategi impelemtansi Revitalisasi SMK $\quad(10$ Langkah Revitalisasi SMK). Buku Serial Revitalisasi SMK. Direktorat Pembinaan Sekolah Menengah Kejuruan. Direktorat Jenderal Pendidikan Dasar dan Menengah Kementrian Pendidikan dan Kebudayaan.

Hasbi. (2017). ). Kontribusi antara pengalaman prakerin, dan peran guru terhadap minat berwirausaha siswa SMK Program Studi Keahlian Teknik Bangunan di Malang. 
Jurnal Pertanian berkelanjutan. Volume 5 No. 2. ISSN: 2302- 6944

Heck, Shirey F. \& Williams, C. Ray. (1984). The Complex Roles oh the Theacher: An Ecological Perspective. Teachers College, Colombia University. New York and London.

Husain L. (2017). Profil Keguruan Menjadi Guru Profesional. Yogyakarta: Pustaka Baru Press.

Hurst, Jessica L.; Thye, Ann; Wise, Chris Leiran. (2014). Internships: The Key to Career Preparation, Professional Development, and Career Advancement. Journal of Family \& Consumer Sciences, Volume 106, Number 2, Spring 2014, pp. 58-62(5).

Iswanu, Sutarto (2016). Kontribusi Prestasi Belajar Prakarya-Kewirausahaan dan Peran Guru sebagai Agen Perubahan dalam Proses Pembelajaran Terhadap Minat Berwirausaha Siswa Kelas XII Jurusan Teknik Bangunan SMK Negrei 1 Seyegan Tahun ajaran 2015/2016. EJournal Pendidikan Teknik Sipil dan Perencanaan. Volume 4, No 5.
Leino J.K., Ruskovaara E., Ikavalko M., Mattila J., \& Rytkola T. (2010). Promoting entrepreneurship education: the role of the teacher?. Education + Training, Vol. 52 Iss 2 pp. $117-127$.

Leino J.K., Satuvuori T., Ruskovaara E., Hannula H., (2015). How do Finnish teacher educators implement entrepreneurship education?. Education + Training, Vol. 57 Issue: 4, pp.392-404, https://doi.org/10.1108/ET-03-2013-0029.

Oplatka, I. (2014). Understanding teacher entrepreneurship in the globalized society. Journal of Enterprising Communities: People and Places in the Global Economy, $8(1), \quad 20-33 . \quad$ doi:10.1108/jec-06-20130016.

Sudira. (2016). TVET Abad XXI: Filosofi, Teori, Konsep dan Strategi Pembelajaran Vokasional. Yogyakarta: UNY Press.

Simpson, D. J, Jackson M.P, Aycock J.C \& Oaks T. (2007: 69). John Dewey and the Art of Teaching: Toward Reflective and Imaginative Practice. Paideusis, Volume 16 (2007), No. 1, pp. 69-71. 